\title{
Does EU Cohesion Policy affect Territorial Inequalities and Regional Development?
}

Lionel Védrine \& Julie Le Gallo

CESAER, AgroSup Dijon, INRAE, Université Bourgogne Franche-Comté.

\section{Abstract}

We extend the literature on Cohesion Policy effectiveness by considering how the cohesion policy affects both within regional disparities and economic growth. For that purpose, a panel database of 205 NUTS2 regions of the UE-25 for 2000-2014 is used. We estimate panel data regressions with fixed effects and a spatial autoregressive term in order to control for unobservable characteristics and spatial dependence. Our results emphasize a trade-off between within and between regional disparities for EU-25 regions over the 2000-2014 period.

Keywords: Cohesion Policy; Regional Development; Within regional disparities; Spatial Panel Econometrics.

Please cite: Védrine, L., \& Le Gallo, J. (2021). Does EU Cohesion Policy affect territorial inequalities and regional development?. EU Cohesion Policy and Spatial Governance: Territorial, Economic and Social Challenges. Cheltenham, UK and Northampton, MA, USA: Edward Elgar Publishing. 


\section{Introduction}

The empirical literature devoted to regional economic disparities in Europe is substantial. The finding of persistent and even growing spatial disparities within countries and regions of the European Union has generated considerable interest among academics and politicians. Indeed, this issue of territorial inequalities is important to consider for both political and economic reasons.

First, politically, territorial inequalities undermine the constitutive objectives of the European Union of social and economic cohesion (European Commision, 2014). The reduction of disparities between the levels of development of regions is a major objective of the European Union since its creation. Also, territorial inequalities have a detrimental impact on social cohesion and lead to political instability. The European Union is currently experiencing a difficult phase that questions its legitimacy. Citizens are increasingly distrustful towards public and political action targeting both their respective Member States and the European Union, which is reflected by the last national elections results (Dijkstra et al., 2019).

Second, economically, in the long run, rising territorial inequalities could affect the growth of all European regions (Brülhart and Sbergami, 2009; De Dominicis, 2014). Cohesion Policy, the regional policy of the European Union, is put in place to encourage the development of territories suffering from economic backwardness, to favor opportunities for the most fragile people (in particular on the labor market) and to ensure a balanced and polycentric development between territories of the European Union. For the 2014-2020 programming period, the budget devoted to Cohesion Policy represents 351.8 billion euros with the objectives of supporting job creation, business competitiveness, economic growth and sustainable development.

In this context, this chapter analyzes the impact of European Cohesion Policy on both regional growth and within regional inequalities linked to the Williamson Hypothesis (Williamson, 1965). Evaluating the impact of this policy has generated an abundant literature involving various evaluation methods and strategies such as Barro regressions augmented with structural funds and potentially controlling for their endogeneity with instrumental variables or a system GMM estimator (Cappelen et al., 2003; Beugelsdijk and Eijffinger, 2005; Dall'Erba and Le Gallo, 2008; Mohl and Hagen, 2010; Bouayad-Agha et al., 2013; Le Gallo et al., 2011), generalized 
propensity score estimation (Becker et al., 2012), regression discontinuity design (Becker et al., 2010, 2013, 2018; Gagliardi and Percoco, 2017) or a control function approach (Coppola et al., 2018). Yet, no consensus has been reached on the effectiveness of this policy. Furthermore, while many studies have documented the effect of cohesion policy on regional growth using the economic convergence model and performing the analysis at the NUTS2 level, the effect of this policy on the evolution of economic disparities within regions has been largely ignored. Finally, most papers focus on the average effect(s) of the cohesion policy, while this policy is implemented differently across European regions and under very different economic conditions.

To fill these gaps, we extend the literature by considering how the cohesion policy affects both within regional disparities and regional development. By using a sample of 205 NUTS2 EU-25 regions from 2000 to 2014 , we estimate panel data regressions with fixed effects and spatial autoregressive terms in order to control for unobservable regional characteristics and spatial dependence.

The chapter is structured as follows. In section 2, we present our estimation strategy and the econometric models we estimate. Section 3 describes the sample and data. We report and interpret the results in section 4. Finally, section 5 concludes with a summary of our main findings and suggests further extensions of our work.

\section{Econometric Methods}

We use the Williamson hypothesis and the neoclassical growth framework to model respectively the dynamics of spatial disparities and economic growth. These two models allow estimating the main determinants of the evolution of the spatial distribution of economic activity both within regions (Williamson, 1965) and between regions. As our sample is a panel of regions, we include individual fixed effects in our specifications to remove unobserved heterogeneity that could be correlated with structural funds' allocation and thus generate a significant bias in the estimation of SF elasticities.

While panel data models with individual fixed effects are commonly used in regional growth equations, their use are more limited to assess the evolution of within spatial disparities due to a small within individual variation. Indeed, the theoretical mechanisms put forward by Williamson 
are based on structural changes that implement gradually. Hence, we first estimate a "Williamson" specification which includes time and country fixed effects:

$\ln \left(C V_{i, t}\right)=\alpha+X_{i, t-1} \beta+C P_{i, t-1} \theta+\lambda_{t}+\omega_{c}+\epsilon_{i, t}$

where $C V$ is a measure of spatial disparity defined below (eq.2); $X$ is a matrix containing the observations for a range of variables (all expressed in logs) at the source of spatial disparities; $C P$ is a matrix of observations pertaining to Cohesion policy variables (all expressed in logs). The country fixed effects $\omega_{c}$ control for invariant unobserved national heterogeneity, $\lambda_{t}$ for yearly common shocks, and $\epsilon_{i, t}$ an iid error term.

Following Artelaris and Petrakos (2016), we measure spatial disparities using a population-weighted coefficient of variation of GDP per capita at the NUTS3 level:

$C V_{i, t}=\frac{\left[\sum_{k}\left(G D P_{k}-\overline{G D P}\right) \times\left(\text { oop }_{k} / \text { pop }\right)^{1 / 2}\right]}{\overline{G D P}}$

where $G D P_{k}$ is the NUTS3 Gross Domestic Product (GDP); $\overline{G D P}$ the average GDP at NUTS2 level; op $_{k}$ and pop are respectively the population at NUTS3 and NUTS2 levels.

The matrix $X$ contains the regional characteristics that potentially affect the dynamics of spatial inequalities and SF allocation. We introduce the initial GDP per capita $\left(\frac{G D P}{p o p}\right)$ and its squared, according to Williamson (1965) who describes a quadratic relationship between spatial disparities and initial development. We also introduce regional quality of government, employment density, population growth, investment rate and sectoral composition of employment as additional control variables. Following the empirical literature on the Williamson hypothesis, we finally add the surface for each NUTS2 regions, the number of NUTS3 regions in the NUTS2 region $i$ and a dummy for membership to the EU-15.

We test several possibilities for $C P$. First, we introduce a dummy for Objective 1 program participation and the total amount of structural funds per gdp for the NUTS2 region $i$ at the year $t-1$. Second, in order to capture potential heterogeneity in the effects of structural funds on 
spatial disparities, we break down the total funds amounts by each type fund (Rodriguez-Pose and Fratesi, 2004); namely the Cohesion Fund (CF), the European Regional Development Fund (ERDF), the European Agricultural Fund for Rural Development (EAFRD) and the European Social Fund (ESF).

Estimating the elasticities of spatial disparities and economic growth with respect to Structural Funds is a difficult task as the allocation of Structural Funds is not random. This allocation depends on observable characteristics of the regions, such as its initial GDP level, population growth, or employment density. Hence, for these determinants, we control the allocation of funds by introducing these variables into our estimates. However, we cannot exclude the presence of unobserved characteristics (unobserved heterogeneity) or omitted variables (due to data availability), which affect both the allocation of Structural Funds and our outcome variables, i.e. within regional disparity and GDP growth. For example, the allocation of funds between regions may depend on political and institutional mechanisms that may also affect spatial disparities and development (Bouvet and Dall'Erba, 2010; Védrine, 2020). The introduction of regional fixed effects allows us to control unobserved heterogeneity invariant over time and thus partially eliminates this issue. Thus, we estimate a two-way fixed effect panel model for spatial disparities:

$\ln \left(C V_{i, t}\right)=\alpha+X_{i, t-1} \beta+C P_{i, t-1} \theta+\lambda_{t}+\mu_{i}+\epsilon_{i, t}$

The matrix $C P$ is similar as in equation (1). We remove time invariant variables from the $X$ set of regional characteristics ${ }^{1} . \mu_{i}$ and $\lambda_{t}$ are respectively individual and time fixed effects, while $\epsilon_{i, t}$ is the error term of our model.

The second model we estimate is a two-way fixed effect panel model for economic growth:

$$
\ln \left(\frac{(G D P / p o p)_{i, t}}{(G D P / p o p)_{i, t-1}}\right)=\alpha^{\prime}+X_{i, t-1} \beta^{\prime}+C P_{i, t-1} \theta^{\prime}+\lambda_{t}^{\prime}+\mu_{i}^{\prime}+\epsilon_{i, t}^{\prime}
$$

\footnotetext{
1 The within estimator applies to data expressed as deviations from the individual means, which implies that we can not identify the effect of time invariant variables.
} 
where the GDP per capita growth rate is expressed as a function of the initial GDPper capita, investment rate, regional quality of government, employment density, population growth and sectoral composition of employment.

In both cases, the estimated SF elasticities might be biased due to the omission of spatial spillover effects (Dall'Erba and Le Gallo, 2008; Bouayad-Agha et al., 2013). Indeed, since SF affect regional growth and spatial disparities of a region $i$, the presence of spatial spillovers between region $i$ and its neighborhood causes the other regions' growth to be indirectly affected by the effect of the funds received by the region $i$ (Mohl and Hagen, 2010). We capture spatial spillovers by considering a Spatial Autoregressive (SAR) term in the 2-ways FE model (SAR 2-ways FE):

$\ln \left(C V_{i, t}\right)=\rho \sum_{i \neq j} w_{i, j} \ln \left(C V_{j, t}\right)+X_{i, t-1} \beta+C P_{i, t-1} \theta+\lambda_{t}+\mu_{i}+\epsilon_{i, t}$

where $\sum_{i \neq j} w_{i, j} \ln \left(C V_{j, t}\right)$ is the spatially lagged spatial disparities. $w_{i, j}$ is part of a spatial weighting matrix $W$ in which spatial connectivity relationships between regions are defined. The spatial autoregressive panel data model with 2-ways FE for growth is defined similarly:

$\ln \left(\frac{(G D P / p o p)_{i, t}}{(G D P / p o p)_{i, t-1}}\right)=\rho^{\prime} \sum_{i \neq j} w_{i, j} \ln \left(\frac{(G D P / p o p)_{j, t}}{(G D P / p o p)_{j, t-1}}\right)+X_{i, t-1} \beta^{\prime}+C P_{i, t-1} \theta^{\prime}+\lambda_{t}^{\prime}+\mu_{i}^{\prime}+\epsilon_{i, t}^{\prime}$

where $\sum_{i \neq j} w_{i, j} \ln \left(\frac{(G D P / p o p)_{j, t}}{(G D P / p o p)_{j, t-1}}\right)$ is the spatially lagged regional gdp growth.

We use Maximum Likelihood to estimate the SAR 2-ways FE (Lee and Yu, 2010) in order to account for the endogeneity of the spatial autoregressive term.

\section{Sample and data}

Our analysis covers 205 NUTS2 regions (2013) in the EU-25 over the period 2000-2014, corresponding to the 2000-2006 and 2007-2013 programming periods of the Cohesion Policy. In order to assess the heterogeneity between the effects of SF on within regional disparities, we 
decompose the full sample in two sub-samples grouping respectively the 170 regions belonging to the EU-15 Member States (EU-15 sub-sample, hereafter) and the 35 regions belonging to the New Member States (NMS sub-sample, hereafter).

All variables are measured annually, including SF payments. Socio-Economic data come from Cambridge Econometrics' European Regional Database (ERD). GDP is expressed in euros (at constant prices of the year 2000). Investment is measured by the total Gross Fixed Capital Formation (in euro), population (in inhabitants), surface (in hectare) and employment by economic sector (Agriculture, Upper tertiary, Industry, Non market services)².

With respect to institutional quality, we cannot directly use the Regional Quality of Government index produced by the Gothenburg Institute (Charron et al., 2014) because this indicator is not available before 2011. Therefore, similarly to Di Cataldo and Rodriguez-Pose (2015), we construct a Regional Quality of Government indicator by combining the Quality of Government Database and the World Bank Global Governance Indicators (WBGI).

The SF payments come from DG Regio database, prepared for the $30^{\text {th }}$ anniversary of the Cohesion Policy. This database contains all the annual payments of the Cohesion Fund (CF), European Fund of Regional Development (ERDF), European Agricultural Fund for Rural Development (EAFRD) and the European Social Fund (ESF). All payments are expressed per gdp.

\section{Results}

\subsection{Effects of SF on within regional disparities}

Table 1 displays the estimation results for equations (1), (2) and (5). The first two columns correspond to the results with time and countries fixed effects, while columns (3) to (6) present respectively the results of 2-ways FE (columns (3) and (4)) and SAR 2-ways FE (columns (5) and (6)). For each model, the first set of results concerns the model with the total amount of SF per GDP while the second set of results breaks down the total funds by each type of fund. For columns (3)-(6) containing region fixed effects, the time invariant variables have been removed.

\footnotetext{
${ }^{2}$ Descriptive statistics are available upon request.
} 
First, the coefficients associated with the initial level of gdp per capita are never significant with values ranging from $-0.007(+/-0.025)$ to $0.009(+/-0.007)$, a result not consistent with the Williamson hypothesis. The coefficients associated to the squared term are significantly positive $(0.074 ;+/-0.014$ and $0.073 ;+/-0.013)$ in the time and countries FE estimations, but are not significant with regional fixed effects. As in Artelaris and Petrakos (2016), we confirm that European within regional disparities do not support the Williamson hypothesis.

The inclusion of regional fixed effects also influences the estimates for population growth, regional quality of government, employment density and agricultural employment by inverting their signs. In columns (1) and (2), the quality of government seems to influence negatively the evolution of within regional disparities $(-0.022$ and $-0.025 ;+/-0.004)$ : a better quality of government is related with smaller within regional disparities, in line with previous results (Ezcurra and Rodriguez-Pose, 2014). Nevertheless, the introduction of regional fixed effects invert the interpretation: a positive variation quality of government leads to a small increase of the within regional disparities (around 0.008).

The elasticities of within regional disparities with respect to both the total amount of Structural Funds are reported in columns (1), (3) and (5) of Table 1 and for each fund separately in columns (2), (4) and (6) of Table 1. Except for column (1), the SF per gdp is positively related with within regional disparities. The estimated elasticities are relatively small (table 1 , columns (3); table 3, first line). For example, the raw elasticity estimated using 2 -ways FE is about $0.6 \%$ $(+/-0.2 \%)^{3}$. This result could be explained since national/regional governments allocate SF mainly to the most developed territories, or to investments favoring the latter.

For regional economic growth, Rodriguez-Pose and Fratesi (2004) show that breaking down each fund targeting a specific objective leads to contrasted results. We adopt a similar strategy to estimate the elasticity with respect to each fund (Table 1, columns (2), (4), table 2 for SAR 2-ways FE). In the estimation including time and country FE, only Cohesion Fund per gdp are not significantly related to the evolution of within regional disparities. ERDF/gdp affect positively within regional disparities (2.9\%; +/- 0.9\%), while EAFRD/gdp and ESF/gdp are strongly related with a decrease of within regional disparities (respectively raw elasticities of $-11.3 \%$ and $-6 \%$; +/$1.5 \%$ ). The negative effects of EAFRD and ESF seem consistent with the objectives of these

\footnotetext{
${ }^{3}$ Doubling SF per gdp amount leads to an increase of $0.6 \%$ of the within regional disparities.
} 
funds, aimed at increasing rural development and promoting the integration of the most vulnerable people. We admit that it appears to be of a very large magnitude, which suggests that the omission of regional individual effects and spatial spillovers effects leads to biased estimates of these elasticities.

The results obtained by 2-ways FE provide a more contrasted view of the effect of EAFRD/gdp and ERDF/gdp, since the elasticities estimated for these two funds become very small (about twenty times smaller than previous) and non significantly different from zero. The raw elasticity of ESF/gdp is $-0.9 \%(+/-0.5 \%)$ which suggests that subsidized projects can rebalance economic activity within the region. Finally, positive variation of CF/gdp is significantly and positively related with an increase of within regional disparities $(1.1 \% ;+/-0.4 \%)$.

\begin{tabular}{|c|c|c|c|c|c|c|c|c|c|c|}
\hline & \multicolumn{2}{|c|}{ Time and countries $F E$} & \multicolumn{2}{|l|}{ 2-ways $F E$} & \multicolumn{6}{|c|}{$S A R$ 2-ways $F E$} \\
\hline & (1) & (2) & (3) & (4) & (5) & (6) & $\begin{array}{l}(7) \\
\text { EU-15 }\end{array}$ & $\begin{array}{l}(8) \\
\text { NMS }\end{array}$ & $\begin{array}{l}(9) \\
\text { EU-15 }\end{array}$ & $\begin{array}{l}(10) \\
\text { NMS }\end{array}$ \\
\hline GDP per capita & $\begin{array}{l}-0.007 \\
(0.025)\end{array}$ & $\begin{array}{l}0.003 \\
(0.025)\end{array}$ & $\begin{array}{l}0.006 \\
(0.008)\end{array}$ & $\begin{array}{l}0.008 \\
(0.008)\end{array}$ & $\begin{array}{l}0.003 \\
(0.007)\end{array}$ & $\begin{array}{l}0.009 \\
(0.007)\end{array}$ & \multicolumn{2}{|c|}{$\begin{array}{c}0.009 \\
(0.008)\end{array}$} & \multicolumn{2}{|c|}{$\begin{array}{l}0.004 \\
(0.004)\end{array}$} \\
\hline Squared GDP per capita & $\begin{array}{l}0.074^{* * * *} \\
(0.014)\end{array}$ & $\begin{array}{l}0.073^{* * * *} \\
(0.013)\end{array}$ & $\begin{array}{l}-0.007 \\
(0.005)\end{array}$ & $\begin{array}{l}-0.007 \\
(0.005)\end{array}$ & $\begin{array}{l}-0.005 \\
(0.004)\end{array}$ & $\begin{array}{l}-0.006 \\
(0.005)\end{array}$ & \multicolumn{2}{|c|}{$\begin{array}{c}-0.011^{* *} \\
(0.005)\end{array}$} & \multicolumn{2}{|c|}{$\begin{array}{c}-0.013^{* *} \\
(0.005)\end{array}$} \\
\hline Regional quality of government & $\begin{array}{l}-0.025^{* * *} \\
(0.004)\end{array}$ & $\begin{array}{l}-0.022^{* * * *} \\
(0.004)\end{array}$ & $\begin{array}{l}0.009^{* * * *} \\
(0.002)\end{array}$ & $\begin{array}{l}0.009^{* * * *} \\
(0.002)\end{array}$ & $\begin{array}{l}0.008^{* * *} \\
(0.002)\end{array}$ & $\begin{array}{l}0.007^{* * * *} \\
(0.002)\end{array}$ & \multicolumn{2}{|c|}{$\begin{array}{l}0.008^{* * * *} \\
(0.002)\end{array}$} & \multicolumn{2}{|c|}{$\begin{array}{c}0.008^{* * *} \\
(0.002)\end{array}$} \\
\hline Employment density & $\begin{array}{l}0.008^{* * * *} \\
(0.003)\end{array}$ & $\begin{array}{l}0.007^{* * *} \\
(0.003)\end{array}$ & $\begin{array}{l}-0.013 \\
(0.011)\end{array}$ & $\begin{array}{l}-0.017 \\
(0.011)\end{array}$ & $\begin{array}{l}-0.016^{*} \\
(0.010)\end{array}$ & $\begin{array}{l}-0.020^{*} \\
(0.010)\end{array}$ & \multicolumn{2}{|c|}{$\begin{array}{l}-0.010 \\
(0.010)\end{array}$} & \multicolumn{2}{|c|}{$\begin{array}{l}-0.018^{*} \\
(0.010)\end{array}$} \\
\hline Population growth & $\begin{array}{l}0.300 \\
(0.278)\end{array}$ & $\begin{array}{l}0.075 \\
(0.277)\end{array}$ & $\begin{array}{l}-0.193^{*} \\
(0.108)\end{array}$ & $\begin{array}{l}-0.194^{*} \\
(0.108)\end{array}$ & $\begin{array}{l}-0.132 \\
(0.096)\end{array}$ & $\begin{array}{l}-0.153 \\
(0.103)\end{array}$ & \multicolumn{2}{|c|}{-0.116} & \multicolumn{2}{|c|}{-0.100} \\
\hline Investment/gdp & $\begin{array}{l}0.044^{* * * *} \\
(0.008)\end{array}$ & $\begin{array}{l}0.046^{* * * *} \\
(0.008)\end{array}$ & $\begin{array}{l}0.004 \\
(0.004)\end{array}$ & $\begin{array}{l}0.005 \\
(0.004)\end{array}$ & $\begin{array}{l}0.003 \\
(0.003)\end{array}$ & $\begin{array}{l}0.005 \\
(0.004)\end{array}$ & \multicolumn{2}{|c|}{$\begin{array}{c}0.001 \\
(0.004)\end{array}$} & \multicolumn{2}{|c|}{$\begin{array}{l}0.001 \\
(0.004)\end{array}$} \\
\hline Agricultural employment & $\begin{array}{l}0.133^{* *} \\
(0.054)\end{array}$ & $\begin{array}{l}0.233^{* * * *} \\
(0.057)\end{array}$ & $\begin{array}{l}-0.221^{* * *} \\
(0.053)\end{array}$ & $\begin{array}{l}-0.241^{* * *} \\
(0.055)\end{array}$ & $\begin{array}{l}-0.206^{* * *} \\
(0.048)\end{array}$ & $\begin{array}{l}-0.220^{* * * *} \\
(0.052)\end{array}$ & \multicolumn{2}{|c|}{$-0.191^{* * *}$} & \multicolumn{2}{|c|}{$-0.229^{* * *}$} \\
\hline Sup employment & $\begin{array}{l}0.268^{* * * *} \\
(0.097)\end{array}$ & $\begin{array}{l}0.295^{* * *} \\
(0.096)\end{array}$ & $\begin{array}{l}-0.122^{*} \\
(0.066)\end{array}$ & $\begin{array}{l}-0.124^{*} \\
(0.066)\end{array}$ & $\begin{array}{l}-0.123^{* * *} \\
(0.058)\end{array}$ & $\begin{array}{l}-0.126^{* *} \\
(0.062)\end{array}$ & \multicolumn{2}{|c|}{$-0.171^{* * *}$} & \multicolumn{2}{|c|}{$\begin{array}{c}-0.180^{* * *} \\
(0.062)\end{array}$} \\
\hline Industrial employment & $\begin{array}{l}0.075 \\
(0.050)\end{array}$ & $\begin{array}{l}0.065 \\
(0.050)\end{array}$ & $\begin{array}{l}-0.387^{* * *} \\
(0.056)\end{array}$ & $\begin{array}{l}-0.382^{* * *} \\
(0.056)\end{array}$ & $\begin{array}{l}-0.345^{* * * *} \\
(0.051)\end{array}$ & $\begin{array}{l}-0.335^{* * * *} \\
(0.053)\end{array}$ & \multicolumn{2}{|c|}{$\begin{array}{c}-0.324^{* * *} \\
(0.053)\end{array}$} & \multicolumn{2}{|c|}{$\begin{array}{c}-0.308^{* * *} \\
(0.053)\end{array}$} \\
\hline Non market employment & $\begin{array}{l}0.587^{* * * *} \\
(0.075)\end{array}$ & $\begin{array}{l}0.630^{* * * *} \\
(0.075)\end{array}$ & $\begin{array}{l}0.052 \\
(0.053)\end{array}$ & $\begin{array}{l}0.057 \\
(0.053)\end{array}$ & $\begin{array}{l}0.035 \\
(0.046)\end{array}$ & $\begin{array}{l}0.079 \\
(0.050)\end{array}$ & \multicolumn{2}{|c|}{0.072} & \multicolumn{2}{|c|}{$\begin{array}{l}0.081 \\
(0.050)\end{array}$} \\
\hline Total funds/gdp & \multicolumn{2}{|l|}{$\begin{array}{l}-0.029^{* * *} \\
(0.005)\end{array}$} & $\begin{array}{l}0.006^{* * * *} \\
(0.002)\end{array}$ & & \multicolumn{2}{|l|}{$\begin{array}{l}0.005^{* * * *} \\
(0.002)\end{array}$} & $\begin{array}{l}-0.013^{* * *} \\
(0.003)\end{array}$ & $\begin{array}{l}011 * * * \\
(0.002)\end{array}$ & & \\
\hline CF/gdp & & $\begin{array}{l}0.017 \\
(0.011)\end{array}$ & & $\begin{array}{l}0.011^{* * *} \\
(0.004)\end{array}$ & & $\begin{array}{l}0.010^{* * *} \\
(0.004)\end{array}$ & & & $\begin{array}{l}-0.009 \\
(0.005)\end{array}$ & $\begin{array}{l}0.015 * * * \\
(0.006)\end{array}$ \\
\hline ERDF/gdp & & $\begin{array}{l}0.029^{* * * *} \\
(0.009)\end{array}$ & & $\begin{array}{l}0.001 \\
(0.003)\end{array}$ & & $\begin{array}{l}0.002 \\
(0.003)\end{array}$ & & & $\begin{array}{l}-0.008^{* *} \\
(0.004)\end{array}$ & $\begin{array}{l}0.011^{*} \\
(0.006)\end{array}$ \\
\hline EAFRD/gdp & & $\begin{array}{l}-0.113^{* * * *} \\
(0.015)\end{array}$ & & $\begin{array}{l}0.002 \\
(0.006)\end{array}$ & & $\begin{array}{l}-0.001 \\
(0.005)\end{array}$ & & & $\begin{array}{l}-0.006 \\
(0.007)\end{array}$ & $\begin{array}{l}-0.008 \\
(0.008)\end{array}$ \\
\hline $\mathrm{ESF} / \mathrm{gdp}$ & & $\begin{array}{l}-0.060^{* * *} \\
(0.015)\end{array}$ & & $\begin{array}{l}-0.009^{*} \\
(0.005)\end{array}$ & & $\begin{array}{l}-0.010^{* *} \\
(0.005)\end{array}$ & & & $\begin{array}{l}-0.015^{* * *} \\
(-0.006)\end{array}$ & $\begin{array}{l}-0.011 \\
(0.010)\end{array}$ \\
\hline Objective 1 & $\begin{array}{l}-0.011^{*} \\
(0.006)\end{array}$ & $\begin{array}{l}-0.014^{* *} \\
(0.006)\end{array}$ & $\begin{array}{l}-0.006^{* *} \\
(0.003)\end{array}$ & $\begin{array}{l}-0.006^{* *} \\
(0.003)\end{array}$ & $\begin{array}{l}-0.004^{*} \\
(0.002)\end{array}$ & $\begin{array}{l}-0.005^{* *} \\
(0.002)\end{array}$ & $\begin{array}{l}-0.005^{* *} \\
(0.002)\end{array}$ & $\begin{array}{l}-0.012 \\
(0.010)\end{array}$ & $\begin{array}{l}-0.005^{*} \\
(0.002)\end{array}$ & $\begin{array}{l}-0.011 \\
(0.010)\end{array}$ \\
\hline Nb of NUTS3 & $\begin{array}{l}0.008^{* * * *} \\
(0.0005)\end{array}$ & $\begin{array}{l}0.008^{* * * *} \\
(0.0005)\end{array}$ & & & & & & & & \\
\hline Surface & $\begin{array}{l}0.001 \\
(0.001)\end{array}$ & $\begin{array}{l}0.001 \\
(0.001)\end{array}$ & & & & & & & & \\
\hline EU-15 & $\begin{array}{l}-0.055^{* * *} \\
(0.023)\end{array}$ & $\begin{array}{l}-0.069^{* * *} \\
(0.023)\end{array}$ & & & & & & & & \\
\hline Constant & $\begin{array}{l}-1.383^{* * *} \\
(0.101)\end{array}$ & $\begin{array}{l}-1.444^{* * * *} \\
(0.100)\end{array}$ & & & & & & & & \\
\hline Spatial lag & & & & & $\begin{array}{l}0.434^{* * *} \\
(0.076)\end{array}$ & $\begin{array}{l}0.233^{* * *} \\
(0.037)\end{array}$ & $\begin{array}{r}0.196 \\
(0.0 \\
\end{array}$ & & $\begin{array}{r}0.20 \\
(0 .\end{array}$ & \\
\hline Observations & 2,814 & 2,814 & 2,814 & 2,814 & 2,814 & 2,814 & 28 & & & \\
\hline (pseudo) $\mathrm{R}^{2}$ & 0.624 & 0.633 & 0.056 & 0.057 & 0.081 & 0.083 & 0.0 & & & \\
\hline LM lag test & & & $39.992^{* * *}$ & $43.246^{* * *}$ & & & & & & \\
\hline LM error test & & & $26.301^{* * *}$ & $32.032^{* * *}$ & & & & & & \\
\hline Robust LM lag tests & & & $31.966^{* * *}$ & $20.814^{* * *}$ & & & & & & \\
\hline Robust LM error tests & & & 1.204 & $4.571^{*}$ & & & & & & \\
\hline Hausman test & & & & & $62.397^{* * *}$ & $64.524^{* * *}$ & 115.2 & *** & 118. & $* * *$ \\
\hline
\end{tabular}

Table 1: Estimation results on within regional disparities.

As discussed above, our results might be affected by the omission of regional spatial spillovers. Since there are various possible specifications to model spatial spillovers, we carry out spatial LM test strategy in order to detect the most suitable specification for our study (bottom of Table 
1). These tests reject the absence of spatial autocorrelation in our model and suggest that it is preferable to estimate a Spatial Autoregressive model rather than a Spatial Error model. In addition, the Hausman test on unobserved effects confirms our choice of a fixed effects over the random effects model. Hence, SAR 2-ways FE is the most appropriate model. The estimated spatial lag ranges from 0.43 to 0.23 , which suggests a strong spatial concentration of within regional disparities values (table 1 , columns (5) and (6)).

As the introduction of the spatial lag of within regional disparities induces a spatial multiplier effect (Le Sage and Pace, 2014), we cannot directly interpret the estimated coefficients as elasticities. Instead, Table 2 displays direct, indirect and total effects for each SAR 2-ways FE. In order to explore the heterogeneity between EU-15 States and the New Member States, we also estimate a SAR 2-ways FE with spatial regimes ${ }^{4}$ (all coefficients are displayed in columns (7)-(10) of Table 1). Concerning the full sample, Total funds per gdp are positively related with the within regional disparities. The amplitude of the estimated effect seems small $(0.6 \%)$. This effect is explained by the combination of two opposite effects. Indeed, by decomposing the estimate of the effect into two spatial regimes, we show a negative effect of the funds on the disparities, whereas this impact is positive for the NMS regions. This suggest that the funds spent in the EU-15 regions are more allocated to actions reducing within regional disparities: doubling the funds of a region $i$ would induce a decrease of $1.3 \%$ of the within regional disparities of this region. Due to the presence of positive spatial spillovers, a doubling of funds in other regions would result in a $0.3 \%$ decline in the region $i$. Thus, the sum of these two effects generates an elasticity whose value shows that the cohesion policy makes it possible to re-balance the economic activity within the EU-15 regions themselves. Since an increase of SF per gdp is positively related with the within regional disparities $(1.4 \%)$, this result shows that the fund does not generally counter-balance within regional disparities in these countries. On the contrary, the allocation of SF per gdp between projects exacerbates within regional disparities.

These results are confirmed by the estimation of elasticities for each fund (Table 2). For the EU 15 regions, all funds have a negative influence on disparities. The most important elasticity is that associated with the ESF. Only the EAFRD has no significant effect on disparities. For NMS regions, changes in EAFRD and ESF are not significantly related to the variation in disparities. An increase of CF and ERDF is related with an increase of respectively $1.9 \%$ and $1.4 \%$ of within regional disparities.

\footnotetext{
${ }^{4}$ We define two spatial regimes based on the EU-15 membership or NMS membership.
} 


\begin{tabular}{ccccccc}
\hline & \multicolumn{2}{c}{ Within regional disparities } & \multicolumn{3}{c}{ Regional GDP growth } \\
Full sample & Direct effect & Indirect Effect & Total effect & Direct effect & Indirect Effect & Total effect \\
\hline Total funds/gdp & $0.005^{* * *}$ & $0.001^{* *}$ & $0.006^{* * *}$ & $0.017^{* * *}$ & $0.029^{* * *}$ & $0.046^{* * *}$ \\
Objective 1 & $-0.006^{* *}$ & $-0.002^{* *}$ & $-0.008^{* *}$ & 0.005 & 0.008 & 0.013 \\
CF/gdp & $0.010^{* * *}$ & $0.003^{* *}$ & $0.013^{* * *}$ & -0.001 & -0.001 & -0.001 \\
ERDF/gdp & 0.002 & 0.001 & 0.002 & $0.018^{* * *}$ & $0.030^{* * *}$ & $0.051^{* * *}$ \\
EAFRD/gdp & -0.001 & -0.001 & -0.001 & $-0.019^{*}$ & $-0.030^{*}$ & $-0.051^{*}$ \\
ESF/gdp & $-0.010^{* *}$ & $-0.004^{*}$ & $-0.013^{* *}$ & 0.012 & 0.021 & 0.033 \\
& & & & & & \\
\hline EU-15 & Direct effect & Indirect Effect & Total effect & Direct effect & Indirect Effect & Total effect \\
\hline Total funds/gdp & $-0.013^{* * *}$ & $-0.003^{* * *}$ & $-0.016^{* * *}$ & -0.008 & -0.014 & -0.023 \\
Objective 1 & $-0.005^{* *}$ & $-0.001^{* *}$ & $-0.006^{* *}$ & 0.003 & 0.004 & 0.007 \\
CF/gdp & $-0.009^{*}$ & -0.002 & $-0.011^{*}$ & $-0.019^{*}$ & $-0.030^{*}$ & $-0.051^{*}$ \\
ERDF/gdp & $-0.008^{* *}$ & $-0.002^{* *}$ & $-0.010^{* *}$ & 0.001 & 0.002 & 0.003 \\
EAFRD/gdp & -0.006 & -0.002 & -0.008 & 0.017 & 0.029 & 0.046 \\
ESF/gdp & $-0.015^{* * *}$ & $-0.004^{* *}$ & $-0.019^{* * *}$ & $-0.021^{*}$ & $-0.036^{*}$ & $-0.056^{*}$ \\
& & & & & & \\
\hline NMS & Direct effect & Indirect Effect & Total effect & Direct effect & Indirect Effect & Total effect \\
\hline Total funds/gdp & $0.011^{* * *}$ & $0.003^{* * *}$ & $0.014^{* * *}$ & $0.027^{* * *}$ & $0.046^{* * *}$ & $0.073^{* * *}$ \\
Objective 1 & -0.012 & -0.003 & -0.015 & $0.040^{* *}$ & $0.068^{*}$ & $0.110^{* *}$ \\
CF/gdp & $0.015^{* * *}$ & $0.004^{* *}$ & $0.019^{* * *}$ & -0.001 & -0.001 & -0.001 \\
ERDF/gdp & $0.011^{* *}$ & $0.003^{*}$ & $0.014^{* *}$ & $0.046^{* * *}$ & $0.078^{* * *}$ & $0.124^{* * *}$ \\
EAFRD/gdp & -0.008 & -0.002 & -0.010 & $-0.079^{* * *}$ & $-0.137^{* * *}$ & $-0.216^{* * *}$ \\
ESF/gdp & -0.008 & -0.002 & -0.010 & $0.060^{* * *}$ & $0.103^{* * *}$ & $0.163^{* * *}$ \\
\hline
\end{tabular}

Table 2: Total, direct and indirect elasticities of SF on within regional disparities and regional GDP growth.

\subsection{Effects of SF on regional growth}

As in Crescenzi and Giua (2016), we confirm the positive influence of structural funds on the growth of GDP per capita (Table 2). The 2-ways FE estimates of total funds per gdp is similar in magnitude than in previous literature ${ }^{5}$. This effect is also robust to the introduction of the spatial lag with a direct effect (elasticity) of about $1.7 \%$. Our results suggest large regional spillover effects (around 0.65), which leads to large indirect $(2.9 \%)$ and total effects $(4.6 \%)$. This effect is mainly focused on the NMS sub-sample. Conversely, an increase in the total Structural Funds is not significantly related to an increase in growth for the EU-15 regions, while the doubling of these funds would lead to an average increase of $2.7 \%$ in growth in the NMS regions.

The effect of structural funds on NMS gdp growth is mainly explained by the large impact of ERDF per gdp (4.6\%) and ESF per gdp (6\%) also displayed in Table 2. We find a negative

\footnotetext{
${ }^{5}$ e.g. Becker et al. (2010) finds a $2 \%$ of gdp growth caused by 01 program, which corresponds to doubling the amount of total funds per gdp.
} 
influence of the EAFRD per gdp on regional growth (-7.9\%) for NMS regions, as previously shown by Esposti (2007) in a sample of EU-15 regions. The results of the funds taken independently on the growth of the EU 15 regions confirm the absence of significant positive effects. On the contrary, we observe a negative relationship between variation in CF and ESF and the average change in GDP per capita growth.

Comparing the results of the two last subsections, we observe for the EU-15 that the structural funds favor the reduction of within regional disparities, but hamper their (NUTS2) gdp per capita growth, suggesting a trade-off between the reduction of within regional disparities and growth of GDP per capita at the regional level. In addition, we observe a similar trade-off for the NMS regions where SF favors (NUTS2) GDP per capita growth (except EAFRD/gdp) but increasing within regional disparities.

\section{Conclusion}

The main objective of this paper was to contribute to the empirical literature on the Cohesion Policy effectiveness by identifying the impact of Structural Funds both within regional disparities and between regional disparities. Our empirical results emphasize a trade-off between within and between regional disparities for EU-25 regions over the 2000-2014 period. For the EU-25 regions, we show that Structural funds affect positively both within regional disparities and economic development. The regional within disparities of EU-15 regions are negatively impacted by an increase of Structural funds, but without incurring any effect on economic growth. Instead, the Structural Funds allocated to the NMS regions seem to positively influence their economic growth, but exacerbate within regional disparities. In addition, a third trade-off has been highlighted. When funds are involved in the reduction of within regional disparities (e.g. ESF or CF in the case of EU-15), they in turn have a negative or non significant impact on economic growth. Apart from the divide between EU-15 regions and the CEEs, these heterogeneous impacts of structural funds might also be due to the mono-/polycentricity structures of the countries (Meijers and Sandberg, 2020) or different institutional and administrative settings and spatial planning traditions (Cotella and Dabrowski, 2020).

These results suggest some recommendations regarding the implementation of cohesion policy. In particular, it would be appropriate to redefine the objectives of the funds granted to the regions by taking into account all the dimensions of well-being (including inequalities) and not 
only the economic criteria. For that purpose, it is essential to have a targeting tool measuring changes in factors of local well-being more precisely than GDP, as suggested by studies focusing on inclusive growth. The creation of an indicator to monitor the evolution of inequalities and growth seems to us a precondition for improving efficiency in terms of reducing within regional inequalities. This indicator would make it possible to identify the regions for which the economic growth generated by cohesion policy comes at the expense of intra-regional cohesion and to grant these regions aid to limit the harmful effect of growth on inequalities. In addition, CLLDs correspond to a governance structure more suited to the appreciation of local situations, making it possible to improve the effectiveness of cohesion policy on inequalities by making projects initiated locally (local information being closer to the preferences of citizens) and carried by all the actors concerned (private partners, association). The usefulness of CLLDs in taking better account of the evolution of within regional inequalities is however conditional on local institutional quality (limiting the capture of funds by local elites).

\section{References}

Artelaris, P. and G. Petrakos (2016), 'Intraregional spatial inequalities and regional income level in the European Union: Beyond the inverted-u hypothesis', International Regional Science Review, 39 (3), 291-317, 2016.

Becker, S.O., Egger, P.H. and M. Von Ehrlich (2010), 'Going nuts: The effect of eu structural funds on regional performance', Journal of Public Economics, 94 (9-10), 578-590.

Becker, S.O., Egger, P.H. and M. Von Ehrlich (2012), 'Too much of a good thing? On the growth effects of the EU's regional policy', European Economic Review, 56 (4), 648-668.

Becker, S.O., Egger, P.H. and M. Von Ehrlich (2013), 'Absorptive capacity and the growth and investment effects of regional transfers: A regression discontinuity design with heterogeneous treatment effects', American Economic Journal: Economic Policy, 5 (4), 29-77. 
Becker, S.O., Egger, P.H. and M. Von Ehrlich (2018), 'Effects of EU regional policy: 1989-2013', Regional Science and Urban Economics, 69,143-152.

Beugelsdijk, M. and S.C.W. Eijffinger (2005), 'The effectiveness of structural policy in the European Union: An empirical analysis for the eu-15 in 1995-2001', JCMS: Journal of Common Market Studies, 43 (1), 37-51.

Bouayad-Agha, S., Turpin, N. and L. Védrine (2013), 'Fostering the development of european regions: A spatial dynamic panel data analysis of the impact of cohesion policy', Regional Studies, 47 (9), 1573-1593.

Bouvet, F. and S. Dall'Erba (2010), 'European regional structural funds: How large is the influence of politics on the allocation process?', JCMS: Journal of Common Market Studies, 48 (3), 501-528.

Brülhart, M. and F. Sbergami (2009), 'Agglomeration and growth: Cross-country evidence', Journal of Urban Economics, 65 (1), 48-63.

Cappelen, A., Castellacci, F., Fagerberg, F. and B. Verspagen (2003), 'The impact of EU regional support on growth and convergence in the European Union', JCMS: Journal of Common Market Studies, 41 (4), 621-644.

Cotella, G. and M. Dabrowski (2021), Cohesion policy as as driver of Europeanisation: a comparative analysis, this volume.

European Commission (2014), Sixth Report on Economic, Social and Territorial Cohesion. Investment for jobs and growth: Promoting development and good governance in EU regions and cities, Brussels: European Commission.

Charron, N., Dijkstra, L., and V. Lapuente (2014), 'Regional governance matters: Quality of government within European Union member states', Regional Studies, 48(1), 68-90.

Coppola, G., Destefanis, S., Marinuzzi, G. and W. Tortorella (2018), 'European Union and nationally based cohesion policies in the italian regions', Regional Studies, forthcoming. 
Crescenzi, R. and M. Giua (2016), 'The EU cohesion policy in context: Does a bottom- up approach work in all regions?', Environment and Planning A: Economy and Space, 48 (11), 2340-2357.

Dall'Erba, S. and J. Le Gallo (2008), 'Regional convergence and the impact of European structural funds over 1989-1999: A spatial econometric analysis', Papers in Regional Science, 87 (2), 219-244.

De Dominicis, L. (2014), 'Inequality and growth in European regions: Towards a place-based approach', Spatial Economic Analysis, 9 (2), 120-141.

Rodríguez-Pose, A. and M. Di Cataldo (2015), 'Quality of government and innovative performance in the regions of Europe', Journal of Economic Geography, 15(4), 673-706.

Dijkstra, L., Poelman, H. and A. Rodríguez-Pose (2019), 'The geography of EU discontent', Regional Studies, forthcoming.

Esposti, R. (2007), 'Regional growth and policies in the european union: Does the common agricultural policy have a counter-treatment effect?', American Journal of Agricultural Economics, 89 (1):116-134.

Ezcurra, R. and A. Rodríguez-Pose (2014), Government quality and spatial inequality: A cross-country analysis', Environment and Planning A, 46 (7), 1732-1753

Gagliardi, L. and M. Percoco (2017), 'The impact of european cohesion policy in urban and rural regions', Regional Studies, 51 (6), 857-868.

Le Gallo, J., Dall'Erba, S. and R. Guillain (2011), 'The local versus global dilemma of the effects of structural funds', Growth and Change, 42 (4), 466-490.

Lee, L.-F. and J. Yu (2010), 'Some recent developments in spatial panel data models', Regional Science and Urban Economics, 40 (5), 255-271.

LeSage, JP. and R.K. Pace (2014), 'Interpreting spatial econometric models', Handbook of Regional Science, 1535-1552. 
Meijers, E. and S. Sandberg (2020) Territorial cohesion, polycentrism and regional disparities - revisiting and unsolved debate, this volume.

Mohl, P. and T. Hagen (2010), 'Do EU structural funds promote regional growth? New evidence from various panel data approaches', Regional Science and Urban Economics, 40 (5), 353-365.

Rodríguez-Pose, A. and U.Fratesi (2004), 'Between development and social policies: the impact of European structural funds in objective 1 regions', Regional Studies, 38 (1), 97-113.

Védrine, L. (2020), 'Allocation of European structural funds, decentralization and strategic spatial interactions', Regional Studies, 54, 72-82.

Williamson, J.G. (1965), 'Regional inequality and the process of national development: a description of the patterns', Economic Development and Cultural Change, 13 (4), Part 2), 1-84. 